\title{
Mesenchymal Cells in Cartilage Growth and Regeneration "An Immunohistochemical and Electron Microscopic Study"
}

\section{Soliman SA ${ }^{1 *}$ and Abd-Elhafeez $\mathrm{HH}^{2}$}

${ }^{1}$ Department of Histology, Faculty of Veterinary Medicine, South Valley University, Qena 83523, Egypt

${ }^{2}$ Department of Anatomy and Histology, Faculty of Vet Medicine, Assuit University, 71526, Egypt

\begin{abstract}
Two common types of cells involved in cartilage growth; the undifferentiated perichondrial cells and chondrocytes. The perichondrial cells provide new external layers of cartilage matrix and are responsible for appositional growth. Chondrocytes proliferate to produce chondrogenic cells which generate a new interstitial cartilage matrix (interstitial cartilage growth). We previously described a third type of cartilage growth which is a mesenchymal cell-dependent type in the cartilage of the air breathing dendritic organ of catfish. The current study aimed to investigate this phenomenon using histochemical techniques, semi-thin sectioning, TEM and immunohistochemical staining. Typical mesenchymal cells penetrated the cartilage of the air breathing organ. Differentiating chondrogenic cells were detected adjacent to mesenchymal cells. Mesenchymal cells were continued with either the perichondrium or the external mesenchyme. Different stages of chondrogenic cells were identified adjacent to mesenchymal cells. Mesenchymal, chondrogenic and mature chondrocytes expressed type II collagen. Chondrogenic cells secrete elastic and safranin $\mathrm{O}$ positive cartilage matrix. Cartilage remnants and broken lacunae were observed at the site of mesenchymal cells. Mesenchymal cells, perichondrial cells, and chondrocytes had strong immunoreactivity for MMP-9. Mature chondrocytes undergo death leaving empty lacunae which were penetrated by mesenchymal cells. In conclusion, mesenchymal cells were responsible for cartilage matrix degradation and formation of the new matrix. They play a role in growth and maintenance of cartilage.
\end{abstract}

Keywords: Immunohistochemistry; TEM; Cartilage; Interstitial; Growth; Mesenchymal; Catfish

\section{Introduction}

Cartilage growth is accomplished by production of new cartilage matrix. Cells of chondrogenic potential can produce cartilage specific matrix proteins particularly, type II collagen and proteoglycans. Two types of cells are commonly known to be implicated in cartilage growth; the undifferentiated perichondrial cells and chondrocytes. The undifferentiated perichondrial cells act as stem cells for cartilage tissue. They activate to secrete new cartilage matrix forming external layers of cartilage matrix and permit diametric growth of cartilage (appositional cartilage growth). Chondrocytes division yields new progeny of chondrocytes which secrete a new interstitial cartilage matrix (interstitial cartilage growth) [1].

We previously studied the involvement of undifferentiated mesenchymal cells in cartilage growth in the cartilage support of the air-breathing organ of premature catfish and different skeletal elements of quail embryos. The undifferentiated cells are derived from the perichondrium invaded the cartilage matrix and further on differentiate to chondrogenic cells and secrete new cartilage matrix. Interstitial differentiation of the mesenchymal cells provides the growing cartilage with new chondrogenic progenies to allow interstitial growth of cartilage $[2,3]$. In the air-breathing organ of catfish, mesenchymal cells contribute to growth, renewal, and replacement of the existing cartilage.

MMPs (Matrix Metalloproteinase) are calcium-dependent endopeptidases and categorized as a member of metzincin superfamily [4]. Various groups of MMPs are identified regarding to the structural domains and substrate such as collagenases, gelatinases, stromelysins, and membrane type MMPs (MT-MMPs), have different [5]. Gelatinase enzymes are gelatinase A (MMP-2) and gelatinase B (MMP-9). MMP9 has different biological roles including angiogenesis, the migration of immune cells, the activation of cytokines and chemokines, and cancer progression [6]. MMP- 9 degrades different components of extracellular matrix such as collagen types IV, V, XIk', XIVl', elastin, aggrecan, link protein, decorinr, lamininn, entactin, SPARCq, myelin basic proteinm, $\infty 2 \mathrm{Mn}, \infty 1 \mathrm{Pli}$, IL-1 $\beta \mathrm{j}$, proTNF- $\infty \mathrm{k}$ [7].

Many therapeutic strategies are performed using mesenchymal cells for cartilage regeneration. The current study aims to investigate importance of mesenchymal cells during growth and renewal of the cartilage in the air-breathing organ of catfish using histochemical techniques, semi-thin sectioning, TEM, and immune markers to identify enzymatic activity (MMP-9) responsible for penetration of cells and cartilage matrix-secreting cells.

\section{Material and Methods}

The study was carried out on 13 apparent healthy catfish of different size. Juvenile catfishes were caught from the River Nile and transported in a glass pool in the lab. Samples of the air-breathing organ (suprabranchial organ) (Figure 1) were collected from catfish (Clarias gariepinus) ranging from 11 to $27 \mathrm{~cm}$ body length. Samples were used for light histological and immunohistochemical analysis and transmission electron microscopic. All fish measured and deeply anesthetized with benzocaine ( $4 \mathrm{mg} / \mathrm{L}$ ) (Figure 1).

*Corresponding author: Soliman SA, Department of Histology, Faculty of Veterinary Medicine, South Valley University, Qena 83523, Egypt, Tel: 2096 5211281; E-mail: Soha.soliman@yahoo.com

Received September 28, 2016; Accepted October 22, 2016; Published October 30, 2016

Citation: Soliman SA, Abd-Elhafeez HH (2016) Mesenchymal Cells in Cartilage Growth and Regeneration "An Immunohistochemical and Electron Microscopic Study". J Cytol Histol 7: 437. doi: 10.4172/2157-7099.1000437

Copyright: (c) 2016 Soliman SA, et al. This is an open-access article distributed under the terms of the Creative Commons Attribution License, which permits unrestricted use, distribution, and reproduction in any medium, provided the original author and source are credited. 


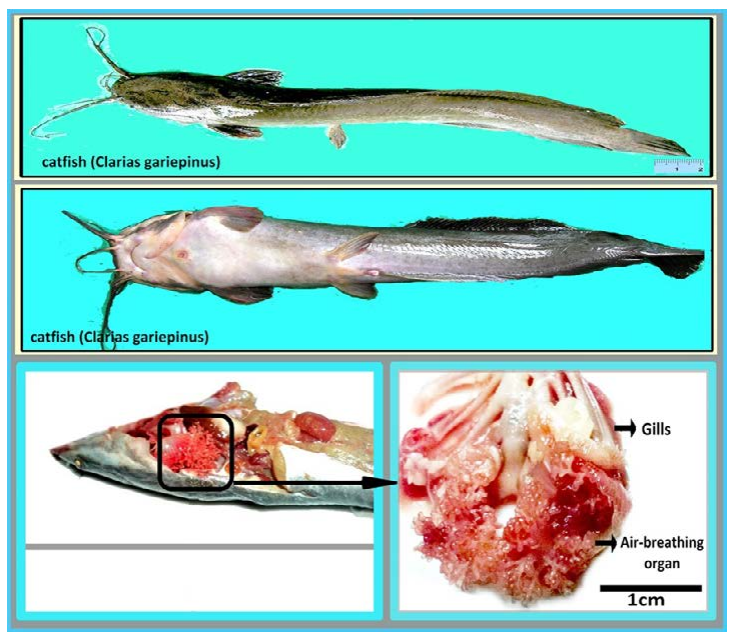

Figure 1: Dissection of air-breathing organ from catfish.

\section{Fixation of samples}

The air-breathing organs were carefully dissected and were immersed in $10 \%$ neutral buffered formalin for paraffin sections and a mixture of $20 \mathrm{~mL}$ of $2.5 \%$ glutaraldehyde and $80 \mathrm{~mL} 0.1 \mathrm{M} \mathrm{Na}$ phosphate buffer ( $\mathrm{pH}$ 7.2-7.4) for semithin sectioning and TEM [8]. Then Specimens were washed by $0.1 \mathrm{M} \mathrm{Na-phosphate} \mathrm{buffer} \mathrm{(} \mathrm{pH} 7.2$ 7.4) before tissue processing for preparation of paraffin blocks.

\section{Histological investigations}

The samples were dehydrated in acceding grades of ethanol $(70,80$, $90,100 \%)$, cleared in methyl benzoate and embedded in paraffin wax. The embedding time was no more than 8 hours. Serial longitudinal and transverse section were obtained at $5 \mu \mathrm{m}$ paraffin. Representative sections were stained with Hematoxylin and eosin stain and safranin O stains used for histological examination $[9,10]$. The sections were dewaxed ( $2 \times 30$ minutes), rehydrated in a descending series of ethanol $(100 \%, 95 \%$, and $70 \%)$ and distilled water. After staining, the sections were dehydrated again in an ascending series of ethanol $(70 \%, 95 \%$, and $100 \%)$, cleared in xylene ( $2 \times 10$ minutes) and mounted with DPX. All staining were cited in Bancroft's theory and practice of histological. Stained sections were examined by Leitz Dialux 20 Microscope. Photos were taken using a Canon digital camera (Canon Powershot A95).

\section{Preparations of resin embedding samples and TEM}

Small specimens measured 2.0-3.0 $\mathrm{mm}$ from the air-breathing organs were used in semi-thin sections. They were washed 4 times for 15 minutes in $0.1 \mathrm{M}$ sodium phosphate buffer ( $\mathrm{pH}$ 7.2) then were post-fixed in $1 \%$ osmic acid in $0.1 \mathrm{M} \mathrm{Na}$-phosphate buffer at $4^{\circ} \mathrm{C}$ for 2 hours. The samples were again washed 3 times for 20 minutes in 0.1 $\mathrm{M}$ phosphate buffer ( $\mathrm{pH}$ 7.2). Dehydration was performed through graded acetone (70,80,90,100\%), 10 minutes for each concentration. The dehydrated samples were immersed in a mixture of acetone/resin ( $1 / 1$ for 1 day, $1 / 2$ for another day) and pure resin for three days. The resin was prepared by using $10 \mathrm{gm}$ ERL, $6 \mathrm{gm}$ DER, $26 \mathrm{gm} \mathrm{NSA}$ and 0.3 gm DMAE and thoroughly mixed by a shaker. The specimens were embedded in the resin at $60^{\circ} \mathrm{C}$ for 3 days. Polymerized samples were cut to semithin sections by using an ultramicrotome Ultracut $\mathrm{E}$ (ReichertLeica, Germany) and stained with toluidine blue (Sodium tetraborate (borax) 1 gram, toluidine blue 1 gram, and Distilled water $100 \mathrm{ml} . \mathrm{s}$ ).
Semi-thin sections were also used in histochemical studies. The sections were treated with a saturated alcoholic solution of sodium hydroxide for 15 minutes to dissolve the resin [11]. The semithin sections were stained by Weigert's elastic stain [12].

Ultrathin sections were obtained by a Reichert ultramicrotome. The sections $(70 \mathrm{~nm})$ were stained with uranyl acetate and lead citrate (Reynolds, 1963) and examined by JEOL100CX II transmission electron microscope at the CENTRAL LABARTORY UNIT of South Valley University.

\section{Immunohistochemical investigations (IHC)}

We used immunostaining to identify the enzymatic activity of cells in tissue, using mouse anti-rabbit antibody against matrix metalloproteinase-9 (MPP-9); a mouse anti-rabbit against MMP9, and detection of cartilage-specific protein type II collagen using a monoclonal mouse anti-chicken antibody against type II collagen. Immunostaining was performed using the Reagent of Ultra Vision Detection System (Anti-Polyvalent, HRP/DAB (ready to use) Thermo Fischer Scientific TP-015-HD) according to the manufacturer's instructions, combined with the Avidin-Biotin Complex (ABC) technique [13].

Immunohistochemical staining was performed on paraffin of the air-breathing organs. Antigen localization was achieved using mouse anti-rabbit antibody against matrix metalloproteinase-9 (MPP-9) combined with the avidin-biotin complex $(\mathrm{ABC})$ technique using the Reagent of Ultra Vision Detection System (Anti-Polyvalent, HRP/ DAB (ready to use, Table 1) Thermo Fischer Scientific TP-015-HD) according to the manufacturer's instructions. Chemical and resources was shown in Table 2.

Staining was done according to the following protocol. Sections $(5 \mu \mathrm{m})$ of paraffin-embedded sections were dewaxed, rehydrated, and rinsed in PBS pH 7.4 (3 times for 5 minutes) (Table 3). Endogenous peroxidase was inhibited by adding drops of hydrogen Peroxide block at room temperature followed by intense washing under running tap water for additional $10 \mathrm{~min}$. For antigen retrieval, slides were placed in $10 \mathrm{mM}$ sodium citrate buffer ( $\mathrm{pH} \mathrm{6.0)}$ and heated to 95-98 in a water bath for 20 minutes followed by cooling for 20 minutes at room temperature. Sections were then rinsed in PBS ( $\mathrm{pH} 7.4,3$ times for 5 minutes). Sections were covered with Ultra $\mathrm{V}$ block, (Table 1, Thermo Fisher scientific, USA) by adding drops cover the sections for 5 minutes at room temperature to block non-specific background staining. Note: Do not exceed 10 minutes or there may be a reduction in the desired stain. Sections were then incubated with the primary antibody overnight at $4^{\circ} \mathrm{C}$ (mouse anti-rabbit antibody against matrix metalloproteinase-9 (MPP-9, RB-9423-PO Thermo Fisher Scientific, UK. Lab Vision corporation; USA) at dilution (1:25) in the PBS. Slides were washed with PBS ( $\mathrm{pH} 7.4,3$ times for 5 minutes), followed by incubation for 10 minutes at room temperature with drops of a biotinylated secondary antibody (Table 1, Biotinylated goat Anti-

\begin{tabular}{|l|c|}
\hline Component & P-015-HD \\
\hline Hydrogen Peroxide Block & TA-015-HP \\
\hline Ultra V Block & TP-015-UB \\
\hline Biotinylated goat Anti-Polyvalent & TP-015-BN \\
\hline Streptaidin Peroxidase & TS-015-HR \\
\hline DAB Plus Substrate & TP-015-HSX \\
\hline DAB Plus Chromogen & TA-001-HCX \\
\hline
\end{tabular}

Table 1: Reagent of UltraVision Detection System (Anti-Polyvalent, HRP/DAB (ready to use) Thermo Fischer Scientific TP-015-HD. 
Citation: Soliman SA, Abd-Elhafeez HH (2016) Mesenchymal Cells in Cartilage Growth and Regeneration "An Immunohistochemical and Electron Microscopic Study". J Cytol Histol 7: 437. doi: 10.4172/2157-7099.1000437

\begin{tabular}{|c|c|c|c|c|c|c|}
\hline \multirow[t]{2}{*}{ Target } & \multicolumn{5}{|c|}{ Primary antibody } & \multirow{2}{*}{$\begin{array}{l}\text { Biotinylated secondary } \\
\text { antibody }\end{array}$} \\
\hline & Supplier & Origin & Dilution & Incubation & Antigen retrieval & \\
\hline Anti-MPP9 & $\begin{array}{c}\text { Thermo Fischer } \\
\text { Scientific, Lab vision } \\
\text { Corporation, Fremont, } \\
\text { USA }\end{array}$ & $\begin{array}{c}\text { Mouse } \\
(\mathrm{mc}, \mathrm{Ab}-1) \\
\text { Clone } \mathrm{D}(33) 376 \\
\text { Rabbit polyclonal }\end{array}$ & $1: 30$ & Over night & $\begin{array}{l}\text { boiling in citrate } \\
\text { buffer }(\mathrm{pH} 6.0) \\
20 \mathrm{~min}\end{array}$ & Goat anti polyvalent \\
\hline \multirow{2}{*}{$\begin{array}{c}\text { Collagen II Ab } \\
\text { 3-3(Clone } 6 \text { b3) }\end{array}$} & \multirow{2}{*}{$\begin{array}{c}\text { Thermo Fischer Scientific, } \\
\text { Lab vision Corporation, } \\
\text { Fremont, USA }\end{array}$} & Mouse anti chicken & \multirow[t]{2}{*}{0.180556} & \multirow[t]{2}{*}{ Over night } & \multirow{2}{*}{$\begin{array}{l}\text { boiling in citrate } \\
\text { buffer }(\mathrm{pH} 6.0) \\
20 \mathrm{~min}\end{array}$} & \multirow[t]{2}{*}{ Goat anti polyvalent } \\
\hline & & (mouse monoclonal & & & & \\
\hline
\end{tabular}

Table 2: Identity, sources, and working dilution of antibodies used in this study.

\begin{tabular}{|c|c|c|}
\hline \multirow{4}{*}{$\begin{array}{l}\text { PBS-buffer ( } \mathrm{pH} 7,2-7,6) \text { : Used } \\
\text { in immunohistochemstry }\end{array}$} & $\mathrm{NaCl}$ & $42.5 \mathrm{~g}$ \\
\hline & $\mathrm{Na}_{2} \mathrm{HPO}_{4} 2 \mathrm{H}_{2} \mathrm{O}$ & $6.35 \mathrm{~g}$ \\
\hline & $\mathrm{NaH}_{2} \mathrm{PO}_{4} \mathrm{H}_{2} \mathrm{O}$ & $1.95 \mathrm{~g}$ \\
\hline & dest. water & ad 5 I \\
\hline \multirow{11}{*}{ Citrate-buffer $(\mathrm{pH} 6,0)$ : } & Solution A: & \\
\hline & Citrate & \multirow[t]{2}{*}{$21.01 \mathrm{~g}$} \\
\hline & $\mathrm{C}_{6} \mathrm{H}_{8} \mathrm{O}_{7} \mathrm{H}_{2} \mathrm{O}$ & \\
\hline & Aqua dest. & ad 11 \\
\hline & Solution B: & \\
\hline & Sodium citrate $\mathrm{Na}_{3} \mathrm{C}_{6} \mathrm{H}_{5} \mathrm{O}_{7} 2 \mathrm{H}_{2} \mathrm{O}$ & $29.41 \mathrm{~g}$ \\
\hline & dest. water & ad 11 \\
\hline & Using solution: & \\
\hline & Solution A: & $9 \mathrm{ml}$ \\
\hline & Solution B: & $41 \mathrm{ml}$ \\
\hline & dest. water & ad $500 \mathrm{ml}$ \\
\hline \multirow{10}{*}{$\begin{array}{l}\text { PBS-buffer ( } \mathrm{pH} 7.2-7.6) \text { : Used } \\
\text { for scanning }\end{array}$} & Solution A: & \\
\hline & $\mathrm{Na}_{2} \mathrm{HPO}_{4} 2 \mathrm{H}_{2} \mathrm{O}$ & $17.02 \mathrm{~g}$ \\
\hline & Aqua dest. & ad $600 \mathrm{ml}$ \\
\hline & Solution B: & \\
\hline & $\mathrm{NaH}_{2} \mathrm{PO}_{4} \mathrm{H}_{2} \mathrm{O}$ & $6 \mathrm{~g}$ \\
\hline & dest. water & ad $250 \mathrm{ml}$ \\
\hline & Using solution: & \\
\hline & Solution A: & $580 \mathrm{ml}$ \\
\hline & Solution B: & $219 \mathrm{ml}$ \\
\hline & dest. water & ad $500 \mathrm{ml}$ \\
\hline
\end{tabular}

Table 3: Solutions used in immunohistochemstry (Bancroft, Layton and Suvarna, 2013).

Polyvalent, Anti-mouse IgG + Anti -Rabbit IgG, Thermo Fisher Scientific, UK. Lab Vision corporation; USA). The slides were thereafter rinsed in PBS ( $\mathrm{pH}$ 7.4, 3 times for 5 minutes) followed by incubation with streptavidin- peroxidase complex (Thermo Fisher Scientific, UK. Lab Vision corporation; USA) for 10 minutes at room temperature. Visualization of the bound antibodies was carried out by adding 1 drops of $\mathrm{DAB}$ plus chromogen to $2 \mathrm{ml}$ of $\mathrm{DAB}$ plus substrate (Table 1 ). Mix well and apply a drop on the tissue. Incubate for 5 minutes at room temperature. Consider, all incubations were performed in a humid chamber. The sections were counterstained with Harris hematoxylin for 30 seconds. The sections were dehydrated in a graded series of alcohols (96\% ethanol, isopropanol I and II), cleared with xylene, and covered with DPX. Negative controls were performed by omission of the primary antibodies. Immunohistochemical staining was evaluated by Leitz Dialux 20 Microscope and photos were photographed by cannon digital camera (Cannon Powershot A95) (Table 3).

\section{Results}

The current study described the involvement of mesenchymal cells in cartilage growth of the air-breathing organ of catfish using specific histochemical staining of cartilage matrix, semi-thin sectioning, TEM. Immune-markers were also used to identify enzymatic activity responsible for penetration of cells and chondrogenic cells.

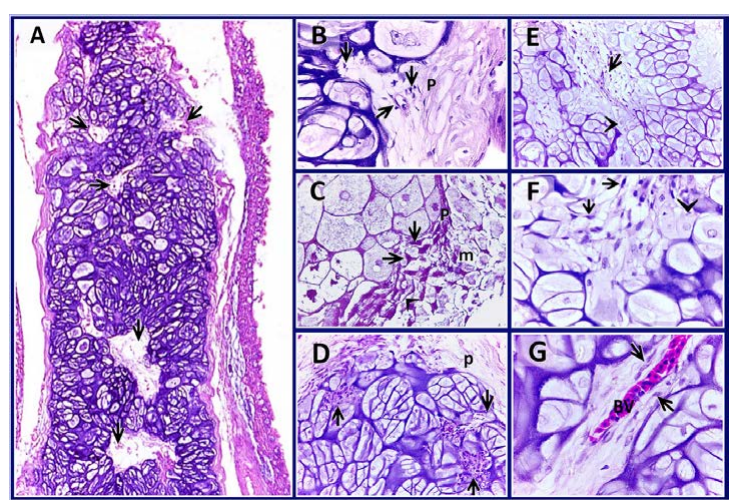

Figure 2: Mesenchymal cells penetration in the supporting elastic cartilage of air-breathing organ. "Paraffin (A-B, D-G) and semi-thin (C) sections of the air breathing organ of catfish stained by $\mathrm{H} \& \mathrm{E}(\mathrm{A}-\mathrm{B}, \mathrm{D}-\mathrm{G})$ and toluidine blue (C). $A, D$ : multiple sites of cellular penetration (arrows) to the elastic cartilage of air-breathing organ. B: the penetrating cells had typical morphological features of mesenchymal cells and appeared small in size (arrows) with cell processes (arrowhead). Mesenchymal cells continued with the perichondrium $(P)$ in $(B)$ which formed of condensed layers of connective tissue. Mesenchymal cells continued with the external mesenchyme $(m)$ in $(C)$ while the perichondrium (P) formed of condensed layers of connective tissue. E, F: Mesenchymal cells (arrows) inside the cartilage and differentiating chondrocytes had rounded morphology (arrowheads). G: blood vessels (BV) in association with mesenchymal cells (arrows).

The supporting cartilage of the air-breathing organ had a unique feature. The cartilage had an irregular contour and multiple sites of cellular penetration (Figure $2 \mathrm{~A}$ and $2 \mathrm{D}$ ). The penetrating cells had typical morphological features of mesenchymal cells and appeared small in size with cell processes. Mesenchymal cells continued with the perichondrium or with the external mesenchyme (Figure $2 \mathrm{~B}$ and 2C). Mesenchymal cells could be observed in association with differentiating chondrocytes (Figure $2 \mathrm{E}$ and $2 \mathrm{~F}$ ). Penetration of mesenchymal cells accompanied by vascular elements (Figure 2). Differentiating chondrocytes produce little amount of elastic and proteoglycan-rich cartilage matrix which stained positive for safranin $\mathrm{O}$ and Weigert elastic stain respectively (Figure 3A-3C). Terminally differentiated chondrocytes and empty lacuna were observed inside the cartilage. Mesenchymal cells filled the vacated areas (Figure 3D and 3E). Mesenchymal cells located adjacent to the broken lacunae (Figure $3 \mathrm{~F}$ and $3 \mathrm{H}$ ) and remnants of cartilage matrix (Figure $3 \mathrm{G}$ and 3I). Semithin sections showed transitional stages of the mesenchymal cells to chondrogenic cells. The cartilage of air-breathing organ composed of chondrocytes located inside their lacunae and areas of mesenchymal cells and differentiating cells (Figure 4A). Mesenchymal cells had cell processes were located adjacent to the perichondrium (Figure. 4B) and inside the cartilage (Figure 4C). Chondrogenic cells which still had cell processes began to secrete extracellular cartilage matrix (Figure 4D and $4 \mathrm{E})$. chondrogenic cells acquired rounded shape and were surrounded by a thin rim of the cartilage septa (Figure $4 \mathrm{~F}$ ). 
Citation: Soliman SA, Abd-Elhafeez HH (2016) Mesenchymal Cells in Cartilage Growth and Regeneration "An Immunohistochemical and Electron Microscopic Study". J Cytol Histol 7: 437. doi: 10.4172/2157-7099.1000437

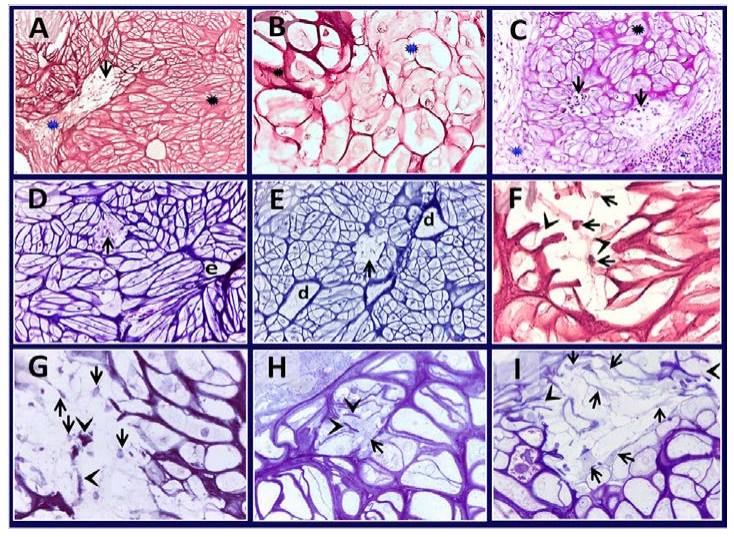

Figure 3: Differentiation of chondrogenic cells, chondrocytes death, and cartilage renewal. "Paraffin $(A-G)$ and semi-thin $(H, I)$ sections of the air breathing organ of catfish stained by safranin $O(A, B, F)$, Weigert elastic stain $(C), H \& E(D, E, G)$ and toluidine blue $(H, I)$. A, B: differentiating chondrocytes secrete around them little amount safranin $O$ positive cartilage matrix (blue asterisk). Note, a large amount of cartilage matrix (black arrows). Mesenchymal cells (arrow). C: sites of mesenchymal cells (arrows) inside the cartilage. Differentiating chondrocytes secrete little elastic fibers richcartilage matrix (blue asterisk). A Large amount of elastic positive cartilage matrix (black arrows). D, E: mesenchymal cells (arrows) inside the cartilage. Note large lacunae contained fully differentiated chondrocytes (d) and empty lacuna (e). F, I: mesenchymal cells (arrows) at the sites where the broken lacunae (arrowheads) existed. G, H: mesenchymal cells (arrows). Remnants of cartilage matrix (arrowheads).

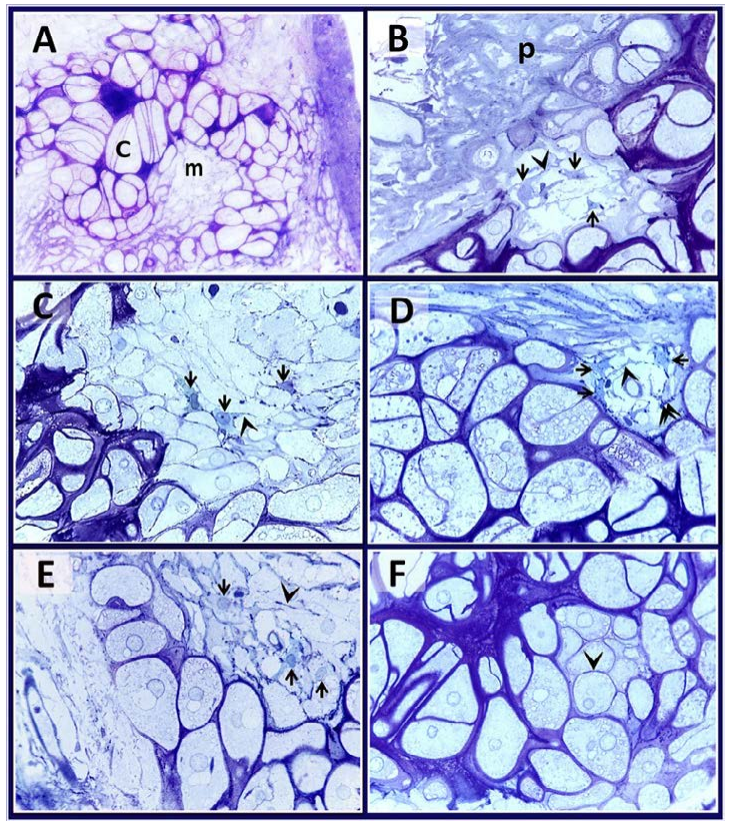

Figure 4: Mesenchymal cell and chondrogenic cells in the cartilage of the airbreathing organ. "Semi-thin sections stained with toluidine blue. A: cartilage of the air breathing organ composed of chondrocytes $(C)$ embedded inside their lacunae and areas of mesenchymal cells $(\mathrm{m})$. B: mesenchymal cells (arrows) with cell processes (arrowhead) in continuous with the perichondrium (P). C: mesenchymal cells (arrows) with cell processes (arrowhead) inside the cartilage of the air breathing organ. D, E: chondrogenic cells (arrows) with cell process (arrowhead) began to secrete little extracellular cartilage matrix (double arrowheads). F: chondrocytes were surrounded by a thin rim of cartilage septa (arrowhead).

By transmission electron microscopy, different stages of chondrogenic cells were observed in the cartilage of air-breathing organ. A flattened chondrogenic cell with scant organelles secreted extracellular matrix (Figure 5B). Chondrogenic cells changed their morphology and secreted more matrix (Figure 5C and 5D). Mature chondrocytes had abundant endoplasmic reticulum (Figure 5).

Mesenchymal cells which penetrated the cartilage matrix expressed MMP-9 as well as perichondrial cells and chondrocytes (Figure 6). Both

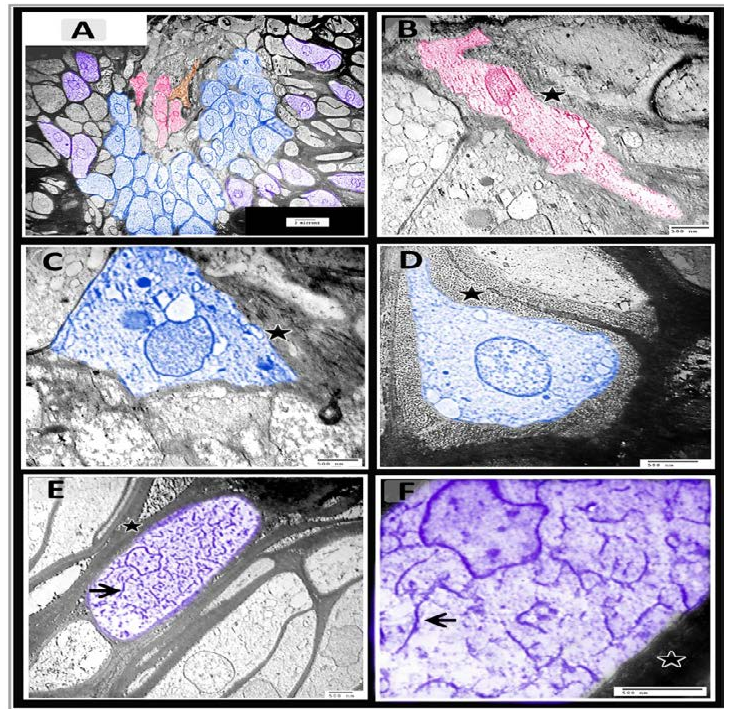

Figure 5: Differentiation of chondrogenic cells in the cartilage of airbreathing organ. Ultra-thin sections of the cartilage of the air-breathing organ. A: mesenchymal cell (brown color), chondrogenic cell (pink colored), differentiating chondrocytes (blue colored), chondrocytes (violet colored) $\mathrm{B}$ : chondrogenic cells had a flattened shape, scant organelles and was surrounded by few cartilage matrices (black asterisk). C: chondrocytes had triangular morphology and surrounded by little cartilage matrix (black asterisk). D: chondrocytes with scant organelles surrounded by fine granular pericellular matrix (black asterisk). E, F: Mature chondrocyte was surrounded by a large amount of cartilage matrix (black asterisk) and was rich in the endoplasmic reticulum (arrows)

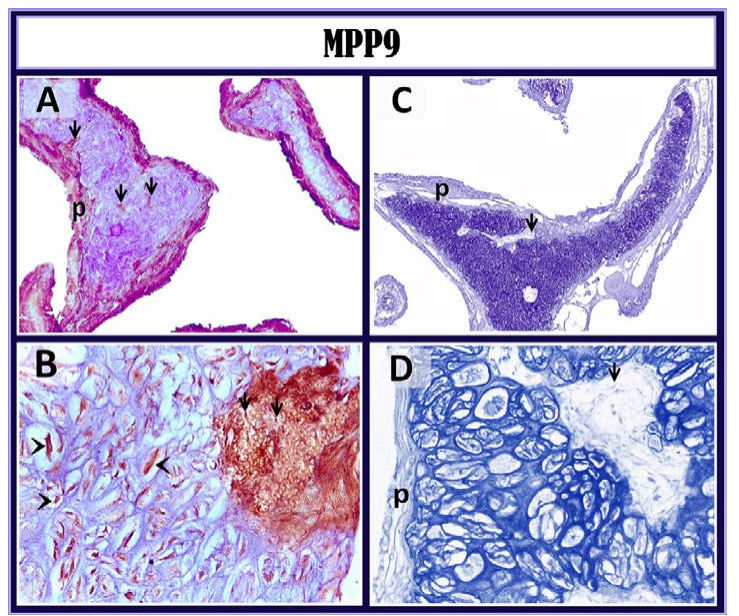

Figure 6: Mesenchymal cells and chondrocytes expressed MMP-9. "Paraffin sections of air-breathing organ immune-stained for MMP-9 in A, B and control negative in C, D. A: the arrows refer to MMP-9 immuno-stained cells inside the cartilage matrix. Note the perichondrial cells had a strong reaction for MMP-9 immunostaining. B: the arrows refer to MMP-9 positive area of mesenchymal cells. The arrowheads refer to MMP-9 immuno-stained chondrocytes. C, D: the arrows refer to the penetrating mesenchymal cells. Note perichondrium $(P)$. 
mesenchymal and chondrogenic cells had immunoaffinity for type II collagen. Mature chondrocytes strongly cytoplasmic immunostaining reaction for type II collagen (Figure 7A and 7B). Mesenchymal cells expressed type II collagen which penetrated the cartilage matrix (Figure 7C and 7D). Mesenchymal cells which extended from the perichondrium also were positively immunostained for type II collagen (Figure 7).

\section{Discussion}

Applications of mesenchymal stem cells have been widely used in tissue engineering and regenerative medicine. Several Biologic therapeutic strategies have been used for cartilage repair. A previously described involvement of mesenchymal cells in cartilage growth and renewal in the air-breathing organ of catfish. The current study aimed to investigate the mode of cartilage growth and repair in the cartilaginous support of the air-breathing organ using histochemical techniques, semi-thin sectioning, TEM. immune markers were used to identify enzymatic activity responsible for penetration of cells and cartilage matrix-secreting cells.

The morphological examination of the cartilage of the air-breathing organ revealed cells penetrating the cartilage had identical features of mesenchymal cells which appeared small in size with cell processes. Mesenchymal cells could be either continued with the perichondrium or the mesenchymal tissue. Similar morphological observations were reported in a previous study. In the present study, mesenchymal cells were accompanied by the invasion of vascular cells. Mesenchymal penetration in the cartilage of the air-breathing organ is similar to that

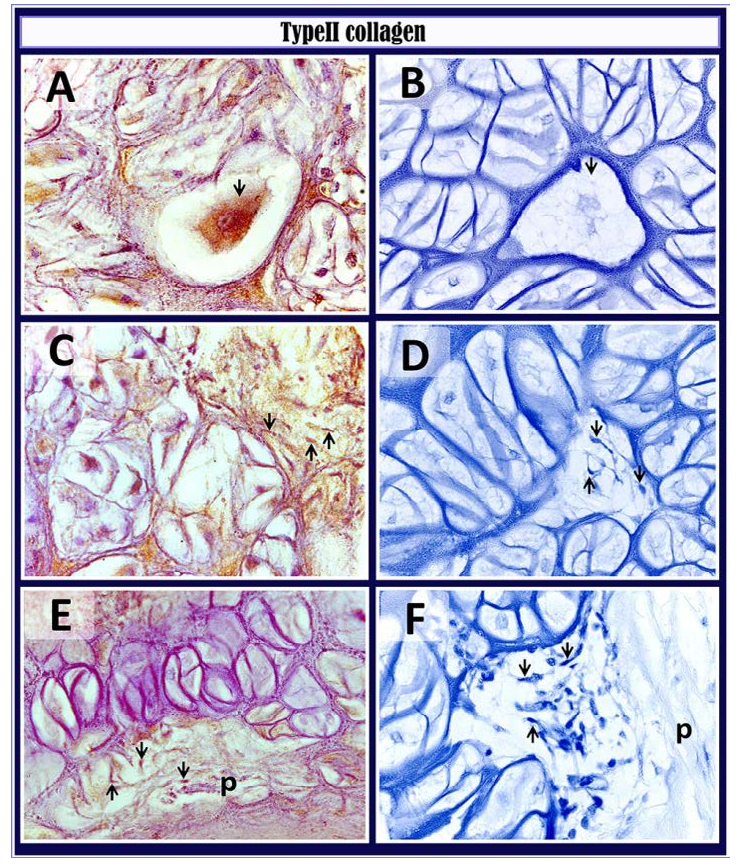

Figure 7: Immunoaffinity of mesenchymal and chondrocytes for type II collagen. Paraffin sections of air-breathing organ immune-stained for Type II collagen in $A, C, E$ and control negative in $B, D, F$. A: the arrow refers to the strong cytoplasmic immuno-stained reaction of the mature chondrocyte for type II collagen. B: the arrow refers to the fine thread-like structure inside the chondrocytes which represent the endoplasmic reticulum. C: type II collagen immuno-stained mesenchymal cells penetrating the cartilage (arrows). D: the arrows refer to mesenchymal cells inside the cartilage matrix. E: mesenchymal cells (arrows) expressed type II collagen. Note the perichondrium $(P)$. F: mesenchymal cells (arrows) extended from the perichondrium $(P)$. occurs during formation of cartilage canals in the epiphyseal cartilage of the developing long bone. Cartilage canals consist of blood vessels, perivascular cells, monocytes, and macrophages [14,15]. In quail embryos, the mesenchymal invasion is recorded in cartilage templates of different skeletal elements. A different pattern of penetrating mesenchymal cells is documented; individual cells, masses of high or low cellular densities and streaks of mesenchymal cells. No vascular cells associate the mesenchymal cells.

Mesenchymal cells were observed in a continuation with the perichondrium or the mesenchyme. We suggested that mesenchymal cells are likely to migrate from the perichondrium or the surrounding mesenchyme.

Transitional stages of chondrogenic cells were recognized by TEM. In the early stages, chondrogenic cells which began to secrete cartilage matrix appeared flattened and had scarce cellular organelles. Chondrogenic cells secreted more matrix. The mature chondrocytes had abundant endoplasmic reticulum. Mesenchymal cells and chondrogenic cells expressed type II collagen while mature chondrocytes had strong immunoaffinity for type II collagen. Moreover, chondrogenic cells to secrete little amount of safranin $\mathrm{O}$ and Weigert elastic positive matrix. The specific cartilage glycoproteins; proteoglycans have affinity for Safranin O stain and Weigert elastic stain react with elastic fibers [16]. We suggested mesenchymal cells penetration had a role in cartilage growth. Cartilage canals contained cells expressing type II collagen and osteogenic cells which express type I collagen and the bone-specific protein, periostin [17-21]. In the current study, mesenchymal penetration and further differentiation may contribute to the uneven growth of the supporting cartilage units and irregular contour of the air-breathing organ. The irregularity of the air breathing organ provides wide respiratory chambers which allow adequate respiration during exposure of the catfish to the air.

In the current study, chondrocytes died leaving empty lacunae which were penetrated by mesenchymal cells and regenerate the cartilage matrix. Thus, mesenchymal cells have a role in cartilage renewal unlike the commonly known in cartilage maintenance. The cellular layer of the perichondrium not only significant in cartilage growth but also maintenance [22].

MMP or matrixins are one of the metal-dependent endopeptidases. MMP destruct the components of extracellular matrix and play a role in remodeling of various types of tissues during physiological or pathological conditions. MMP family comprised of twenty-four groups of matrix metalloproteinase enzymes [23]. Classification of MMPs depends on the structural domains and substrate specificity. The commonly known MMPs are collagenases, gelatinases, stromelysins, and membrane type MMPs (MT-MMPs). MMPs activities is widely recognized during migration and invasion processes such as endothelial cells to enhance migration of neural cells and angiogenesis, cancer cells, embryonic trophoblasts, fibroblasts, neutrophils, eosinophils, macrophages, T-cells, chondrocytes and osteoblasts [24-28]. Two types of gelatinases are identified; gelatinase A (MMP-2) and gelatinase B (MMP-9). MMP-9 promote migration of immune cells, angiogenesis, and progression of cancer cells. MMP-9 breakdown collagen types $\mathrm{IV}, \mathrm{V}, \mathrm{XIk}^{\prime}, \mathrm{XIVl}^{\prime}$, elastin, aggrecan, link protein, decorinr, lamininn, entactin, SPARCq, myelin basic protein, $\infty 2 \mathrm{Mn}, \infty 1 \mathrm{Pli}$, IL-1 $\beta \mathrm{j}$, proTNF$\infty \mathrm{k}$. In the current study, we used immunohistochemical staining to identify MMP-9 expression the cartilage of air-breathing organ. Strong MMP-9-positive mesenchymal cells were detected in the perichondrial connective tissue and the mesenchymal masses inside the cartilage matrix. Areas of mesenchymal cells contained cartilage remnants and 
Citation: Soliman SA, Abd-Elhafeez HH (2016) Mesenchymal Cells in Cartilage Growth and Regeneration "An Immunohistochemical and Electron Microscopic Study". J Cytol Histol 7: 437. doi: 10.4172/2157-7099.1000437

broken lacunae. We suggesting that mesenchymal cells secrete matrix metalloproteinases for degradation of matrix components to invade the cartilage tissue. The proteolytic activity of the mesenchymal cells has been studied by and is required for cellular proliferation and growth of the tissues [29,30]. MMP-9 is identified during degradation of cartilage matrix in osteoarthritis [31]. Members of MMPs family such as MMP3, MMP-2 and MMP-9 are implicated in degradation of the articular cartilage extracellular matrix [32].

In conclusion, mesenchymal cells degraded components of cartilage matrix to penetrated the cartilage and secrete new cartilage matrix including elastic fibers, proteoglycan, and type II collagen. Mesenchymal cells play a role in growth and renewal of cartilage.

\section{Acknowledgements}

This study was conducted in South Valley University and Assuit University.

\section{References}

1. Eroschenko VP, Di Fiore MSH (2013) DiFiore's Atlas of Histology with Functional Correlations. Lippincott Williams \& Wilkins (12thedn) p: 114.

2. Soliman SA (2014) New Aspect in Cartilage Growth "The Invasive Interstitial Type. J Aquaculture Research Development 5: 253.

3. Soliman SA, Abd-Elhafeez HH (2014) Mesenchymal cells in cartilage growth. LAP Lambert Academic Publishing 4: 49.

4. Vandenbroucke RE, Libert C (2014) Is there new hope for therapeutic matrix metalloproteinase inhibition? Nature Reviews Drug Discovery 13: 904-927.

5. Newman MG, Takei H, Klokkevold PR, Carranza FA (2014) Carranza's Clinical Periodontology. Elsevier Health Sciences. 84.

6. Klein T, Bischoff R (2011) Physiology and pathophysiology of matrix metalloproteases. Amino Acids. 412: 271-290.

7. Clendeninn NJ, Appelt K (2001) Matrix Metalloproteinase Inhibitors in Cancer Therapy. Springer Science+Business Media New York, Humana Press.

8. Bancroft JD, Layton C, Suvarna SK (2013) Bancroft's Theory and Practice of Histological Techniques. Churchill Livingstone (7thedn).

9. Harris HF (1898) A new method of ripening hematoxylin. In: Mikroskopische Technik. Romeis (ed.) Oldenburg, München.

10. Tran D, Golick M, Rabinovitz H, Rivlin D, Elgart G, et al. (2000) Hematoxylin and safranin O staining of frozen sections. Dermatol Surg 263: 197-199.

11. Lloyd RV (2001) Morphology Methods: Cell and Molecular Biology Techniques. Springer Science \& Business Media.

12. Weigert C (1898) Über eine Methode zur Färbung elastischer Fasern. ZL. Pathol. 9: 289-292.

13. Hsu S, Raine L, Fanger H (1981) Use of avidin-biotin-peroxidase complex $(A B C)$ in immunoperoxidase techniques: a comparison between $A B C$ and unlabeled antibody (PAP) procedures. J Histochem Cytochem. 294: 577-580.

14. Blumer MJ, Longato S, Richter E, Perez MT, Konakci KZ, et al. (2005) The role of cartilage canals in endochondral and perichondral bone formation: are there similarities between these two processes? J Anat 206: 359-372.

15. Gabner S, Häusler G, Böck P (2014) Vascular channels in hyaline cartilage: development of channels. and removal of matrix degradation products. Anat Histol Embryol.

16. Athanasiou KA, Darling EM, Hu JC, Duraine GD, Hari Reddy A (2013) Articular Cartilage. CRC Press.
17. Le Guellec D, Mallein-Gerin F, Treilleux I, Bonaventure J, Peysson P, et al. (1994) Localization of the expression of type I, II and III collagen genes in human normal and hypochondrogenesis cartilage canals. Histochem J 269: 695-704.

18. Claassen H, Kirsch T, Simons G (1996) Cartilage canals in human thyroid cartilage characterized by immunolocalization of collagen types I, II, pro-III, IV and X. Anat Embryol (Berl) 194: 147-153.

19. Blumer MJ, Fritsch H, Pfaller K, Brenner E (2004) Cartilage canals in the chicken embryo: ultrastructure and function. Anat Embryol (Berl). 207: 453-462.

20. Blumer MJ, Longato S, Fritsch H (2004) Cartilage canals in the chicken embryo are involved in the process of endochondral bone formation within the epiphyseal growth plate. Anat Rec A Discov Mol Cell Evol Biol. 279: 692-700.

21. Blumer MJ, Schwarzer C, Perez MT, Konakci KZ, Fritsch H (2006) Identification and location of bone-forming cells within cartilage canals on their course into the secondary ossification centre. J Anat. 208: 695-707.

22. Gartner LP, Hiatt JL (2007) Color Textbook of Histology. Elsevier Health Sciences. (3rdedn) 132.

23. Ozet OG (2013) Matrix Metalloproteinase Enzyme Family. Archives Medical Review Journal. 2013. 222: 209-220.

24. Wang L, Zhang ZG, Zhang RL, Gregg SR, Hozeska-Solgot A, et al. (2006) Matrix metalloproteinase 2 (MMP2) and MMP9 secreted by erythropoietinactivated endothelial cells promote neural progenitor cell migration. J Neurosci 26: 5996-6003.

25. Itoh $Y$, Nagase $H$ (2002) Matrix metalloproteinases in cancer. Essays Biochem 38: 21-36.

26. Leong HS, Robertson AE, Stoletov K, Leith SJ, Chin, et al. (2014) Invadopodia are required for cancer cell extravasation and are a therapeutic target for metastasis. Cell Rep 8:1558-1570.

27. Zhu JY, Pang ZJ, Yu YH (2012) Regulation of trophoblast invasion: the role of matrix metalloproteinases. Rev Obstet Gynecol. 5: e137-143.

28. Singh G, Rabbani SA (2007) Bone Metastasis.

29. Ghajar CM, Kachgal S, Kniazeva E, Mori H, Costes SV, et al. (2010) Mesenchymal cells stimulate capillary morphogenesis via distinct proteolytic mechanisms. Exp Cell Res. 316: 813-825.

30. Shi J, Son MY, Yamada S, Szabova L, Kahan S, et al. (2008) Membranetype MMPs enable extracellular matrix permissiveness and mesenchymal cell proliferation during embryogenesis. Dev Biol 313: 196-209.

31. Galasso O, Familiari F, De Gori M, Gasparini G (2012) Recent findings on the role of gelatinases (matrix metalloproteinase-2 and -9 ) in osteoarthritis. Adv Orthop.

32. Sandya S, Achan MA, Sudhakaran PR (2009) Multiple matrix metalloproteinases in type II collagen induced arthritis. Indian J Clin Biochem 24: 42-48. 